添加，温度低下などによる HT 80 鋼の腐食割れへの影響 を調ベて，つぎのことを明らかにした。

(1) $\mathrm{HT} 80$ 鋼は㬰験室の液体 $\mathrm{NH}_{3}$ 中では $\mathrm{Al}, \mathrm{Mg}, \mathrm{Zn}$ に対して 1〜1.3V 貴な電位を示す。

（2）現地の液体 $\mathrm{NH}_{3}$ 配管中で， $\mathrm{Al}, \mathrm{Mg}, \mathrm{Zn}$ は表面に腐 食生成物や鉄さびが付着して，犠牲陽極としては WOL 試 験片の腐食割れ防止効果を示さず，A1はむしろ腐食割れ 老助長する。

(3) $30^{\circ} \mathrm{C}$ の促進試験環境下での HT 80 鋼の腐食割れ は，冷涷機油を $0.01 \mathrm{wt} \%$ 以上なた袖油を $0.0005 \mathrm{wt} \%$ 以 上(溶解度の数\%) 添加すると抑制される。一力溶解度の小 さいシリコン油は多量の添加で腐食割れ抑制効果を失う。

（4）腐食割れ促進試験環境下でも蕰度を $10^{\circ} \mathrm{C}$ 以下，む しくは $40^{\circ} \mathrm{C}$ 以上立ると $\mathrm{H} T 80$ 鋼の腐食割れは抑制さ れる、割れを発生する温度での陽分極曲線と，発生しない 温度でのそれとの間には若干の差が多られ，不㗢態皮膜の 安定性と腐食割れとには密接を関係がある。

（5）促進試験環境下での試験結果からみて，油分の存在 と温度低下による腐食割れ抑制效果を国内の液体 $\mathrm{NH}_{3}$ 夕 ンクに適用すると，腐食割れの理由を矛盾なく説明でき， 実タンクでの温度低下による腐食割れ防止効果す顕著にみ られた。
終りに，本研究を行ならにあたり有益な助言をいただ、 た大阪大学溶接工学研究所長 渡辺正紀博士, 当社ェンジ ニアリング研究所技研空長小林辟作博士，開発部主任部

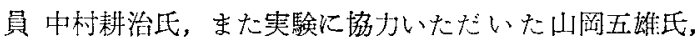
広瀨重雄氏，仁科利男氏に心から感謝の意を表したい。

\section{文献}

(1) A.W.Loginow and E.H.Phelps: Corrosion, 18 (1962), $299 \mathrm{t}$.

(2) D.C.Deegan and B. E. Wilde : Corrosion, 29 (1973), 310.

(3) F.J.Radd and D.H.Oertle : Getter-Iron Probe Studies of Hydrogen Entry Into Iron from Liquid and Gaseous Ammonia Systems, NACE Annual Conference, Chicago, (1971), March.

(4) 今川博之, 中村耕治：金属学会誌, 40(1976)，1250.

（5）今川博之：金属学会誌, 40(1976)，1256.

(6) I.Class und K.Gering: Werkstoff und Korrosion, $25(1974), 314$.

（7）松杰保夫：東北大学非水化学研究所報告，3(1953), 7.

(8) Д.С.Ццклцс и Н.П.Гортоиоба : Ж.Фнз.Хим, $44(1970), 2661$.

(9) 富上 岳, 丸山 温, 佐久閒尚誌：非破壞柍查，昭 和 45 年度春季大会講演概要, 19(1970), 82 .

\title{
液体アンモニア中における高張力鋼の応力腐食割れに およぼす水と空気の影響
}

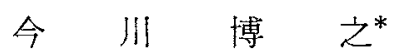

Hiroshi Imagawa : Effects of Water and Air on Stress Corrosion Cracking of High Strength Steel in Liquid Ammonia. Effects of water and ait on the anodic polarization and the stress corrosion cracking (SCC) of a quenched high strength steel in liquid ammonia saturated with $\mathrm{NH}_{4} \mathrm{CO}_{2} \mathrm{NH}_{2}$ (about $0.9 \mathrm{wt} \%$ ) were investigated by using the potentiodynamic and constant strain methods. The results obtained are as follows:

(1) In the above-mentioned environment without water, the steel showed different anodic polarizations and SCC behaviors in the same content of air, according to the kind of gases $\left(\mathrm{N}_{2}\right.$, Ar or $\mathrm{NH}_{3}$ ) with which the air in the test vessel was replaced before filling it with liquid ammonia. SCC of the steel was observed and the air inhibited corrosion and SCC in those environments.

(2) The critical current density of anodic polarization curves increased with increases in water content and temperature and decreased with an increase in air content, respectively. The passive current density decreased with water content and increased with temperature. SCC of steel tended to occur when the critical current density and the passive current density of the anodic polarization curves were high.

(3) In the liquid with more than $0.3 \mathrm{wt} \%$ water, the steel showed a passive potential and did not corrode in presence of air. On the other hand, the steel showed an active potential in the presence of a small amount of air.

(4) In the liquid with water (maximum $1.0 \mathrm{wt} \%$ ), SCC of specimens showing an active 
potential was prevented by addition of $1.0 \mathrm{wt} \%$ water, but it was liable to occur when the contents of air and water were low. And the test results of SCC of specimens showing a passive potential were lacking in reproducibility.

(5) The amount of water neccessary to prevent SCC in a liquid ammonia tank seems to vary with $\mathrm{CO}_{3}^{--}$and $\mathrm{O}_{2}$ contents in the liquid ammonia and its temperature.

(Received June 15, 1976)

\section{I. 緒言}

滈張力鋼の液体フンモニア(以下液体 $\mathrm{NH}_{3}$ ) による応力 腐领割れ(SCC)の防止洼として，Loginow ら (1) は液体 $\mathrm{NH}_{3}$

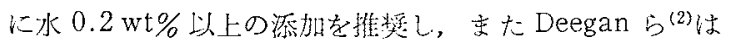
$0.08 \mathrm{wt} \%$ 以上の水添加が有效で市ると報告している。岡 田方 (3) は液体 $\mathrm{NH}_{3}-\mathrm{CO}_{2}$ 系て試験を行ない，割れ防止には $0.2 \sim 0.5 \mathrm{wt} \%$ の水㳢加が有效で西り，隆伏点の高い材料 汪ど多量の水源加が必要であると都している。一方 Radd

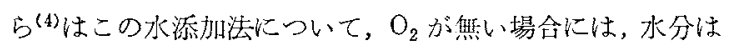
をしろ割れを助長し，割れの防止には水分を同侍に $\mathrm{O}_{2}$ が 必要であると推論している.

著者 ${ }^{(5)}$ は水(イオン交換水)を $0.2 \mathrm{wt} \%$ 添加した液体
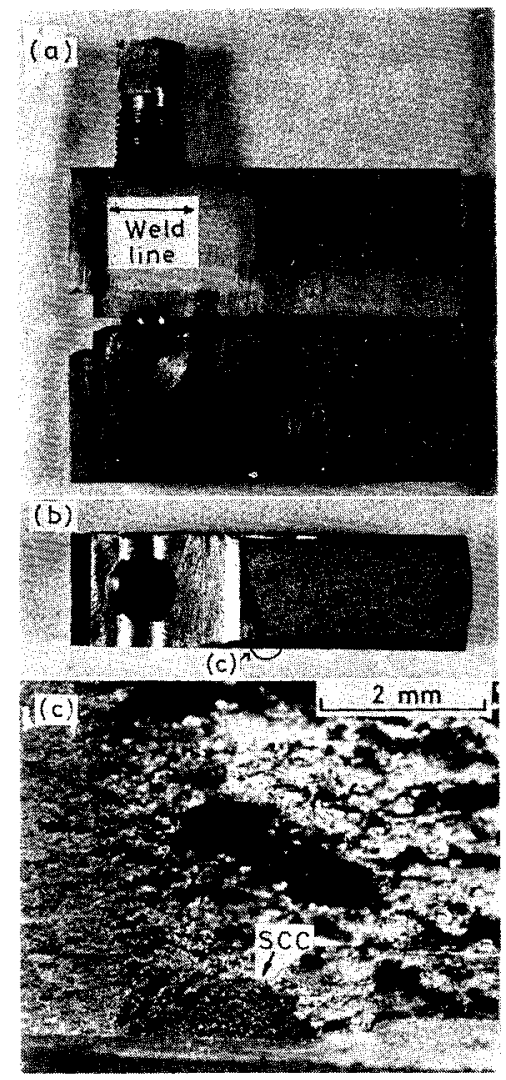

Photo.1 Cracked WOL type specimen in a field tank stored liquid $\mathrm{NH}_{3}$ with 0.25 wt $\%$ $\mathrm{H}_{2} \mathrm{O}$. Material is $80 \mathrm{~kg} / \mathrm{mm}^{2}$ high stren$\mathrm{gth}$ steel. Test period is 4 months. Set $K=200 \mathrm{~kg} / \mathrm{mm}^{3 / 2}$.

(a) Shape of specimen, (b) After mechanical failure, (c) Detail of the SCC surface.
$\mathrm{NH}_{3}$ を， $60 \mathrm{~kg} / \mathrm{mm}^{2}$ 級高娠力鎦 ( $\mathrm{HT}$ 60)製の $1000 \mathrm{M}^{3}$ 大 父温眝藏タンクに入れ，確認試験を行った絬果，試験後の

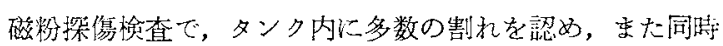
汇浸せきした $80 \mathrm{~kg} / \mathrm{mm}^{2}$ 媇高張力鋼(HT 80)の溶接 WOL 型試験街にも割机を検出した(Photo.1)。このときのタン ク㸚相部の $\mathrm{O}_{2}$ 濃度は $0.038 \sim 0.050 \mathrm{vol} \%$ であった。 また デンマークでも氷分 $0.2 \mathrm{wt} \%$ を含んた液体 $\mathrm{NH}_{3}$ を眝蔵し たタンクに割れが発生している(6)。これらの現象からみ て，液体 $\mathrm{NH}_{3}$ に上る銅の SCC を水添加法て防止する場 合には, 水分量, $\mathrm{O}_{2}$ 湍度や眝蔵溜度に上って防止効果が 異なることが予想される。亦たPhelps ${ }^{(7)}$ は，液体 $\mathrm{NH}_{3}$ 中 ての銅の腐食割れが $\mathrm{N}_{2}$ と $\mathrm{O}_{2}$ の共存下で発生しやすいと して， $\mathrm{N}_{2}$ の必要性を強調している。これから液体 $\mathrm{NH}_{3}$ 冮 での銅の腐食割れは不活性ガスと微量の $\mathrm{O}_{2}$ の共存下で発 生するのではないかと予想される。

本報では，すで報告した ${ }^{(8)(9)}$ 液体 $\mathrm{NH}_{3}$ 腐食割机促進

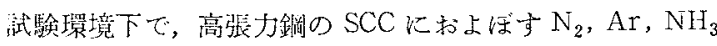
ガスの影繁について，次いで SCC の防止に有効之考党ら 机ている水分と空気中の酸素の影響について, 電気化学的 にその学動を調べるともに，応力腐食制れ武驗を行い， 水分以上る制机抑制の可能性上，その機構，お上び空気中 の酸素や温废の影彗について梖討を加えた。

\section{II. 実 験 方 法}

\section{1. 分極測定}

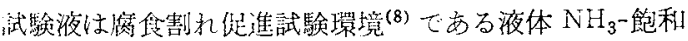
$(0.9 \mathrm{wt} \%) \mathrm{NH}_{4} \mathrm{CO}_{2} \mathrm{NH}_{2}\left(5 \mathrm{wt} \%\right.$ 添加) 系 $\left(30^{\circ} \mathrm{C}\right)$ を選び，基 激の液体 $\mathrm{NH}_{3}$ の組成は $\mathrm{NH}_{3} 99.9 \mathrm{wt} \%, \mathrm{H}_{2} \mathrm{O} 0.05 \mathrm{wt} \%$ ， 油分 $3 \mathrm{ppm}$ のものを用い, $\mathrm{NH}_{4} \mathrm{CO}_{2} \mathrm{NH}_{2}$ は一級試䕗を。 水は蒸留水をそ机ぞれ用いた。

分極測定用試験電極としては前報 ${ }^{(8)(9)}$ の $80 \mathrm{~kg} / \mathrm{mm}^{2}$ 高 㧧力䜽を用い，受入れのまま(焼入・蛄もどし)の状態で試 跧に供した，試験電極の形状ならびに測定容器は前報に同

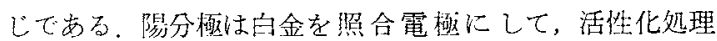
$\left(-3 \mathrm{~V}, 1.3 \mathrm{~mA} / \mathrm{cm}^{2}\right.$ で $\left.10 \mathrm{~min}\right)$ 後, $20 \mathrm{mV} / \mathrm{min}$ の走查 電位法で測是した。

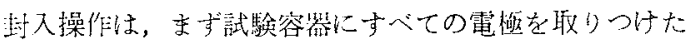
後，科最した $\mathrm{NH}_{4} \mathrm{CO}_{2} \mathrm{NH}_{2}$ を入れ，别体笛した水を入れ たポりエチレン容器を装入して, $\mathrm{NH}_{4} \mathrm{CO}_{2} \mathrm{NH}_{2}$ との直授接 触を避沙る状態にする。次いで, この試験容器を封入系に

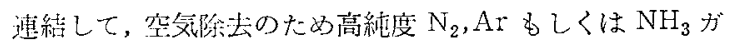
大で $9 \mathrm{~kg} / \mathrm{cm}^{2}$ 加压置換を行った後, 連結管から液体 $\mathrm{NH}_{3}$ を尊入し, $\mathrm{NH}_{3}-\mathrm{NH}_{4} \mathrm{CO}_{2} \mathrm{NH}_{2}-\mathrm{H}_{2} \mathrm{O}$ 系の試験液を調製 


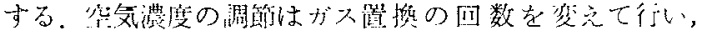

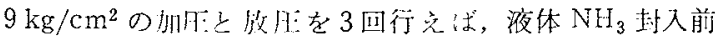
の容器内の突気は計算値で 0.1 vol\%となる。なおがス

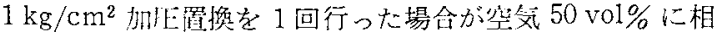
当する。こ机液体 $\mathrm{NH}_{3}$ 封入前の容器队(扵入时に液体

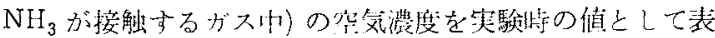
示した。

\section{2. 応力磨食割れ試験}

試娩片は前報 ${ }^{(8)(9)}$ に闻しく，HT 80 材からレノッチの板

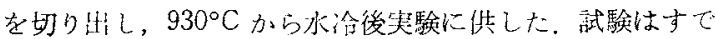

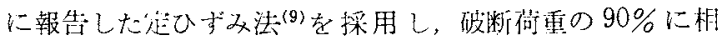
当する変位を与えて，恜験後割れの有㶵を観祭した，容器

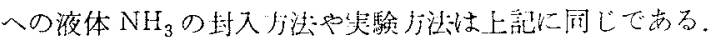

\section{III. 実 験 結 果}

\section{1. 陽 分 極}

\section{（1）空気と不活性ガスの影響}

液体 $\mathrm{NH}_{3}$ 封入前の試験容器内の空氛除去を, $\mathrm{N}_{2}$ 少入の

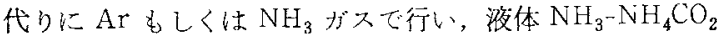

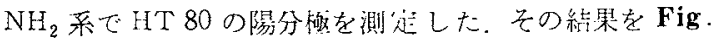
1,2 亿示す。前報の $\mathrm{N}_{2}$ f 大置換の場合には(Fig.3)，空 领が $10 \mathrm{vol} \%$ に増大寸ると，分極曲線の形が大きく紧化し

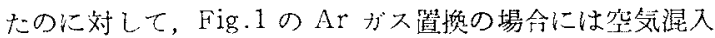
による分極他線の変化は少ない。李た Fig.2の $\mathrm{NH}_{3}$ ガス

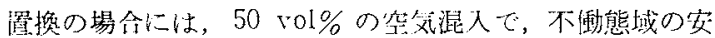

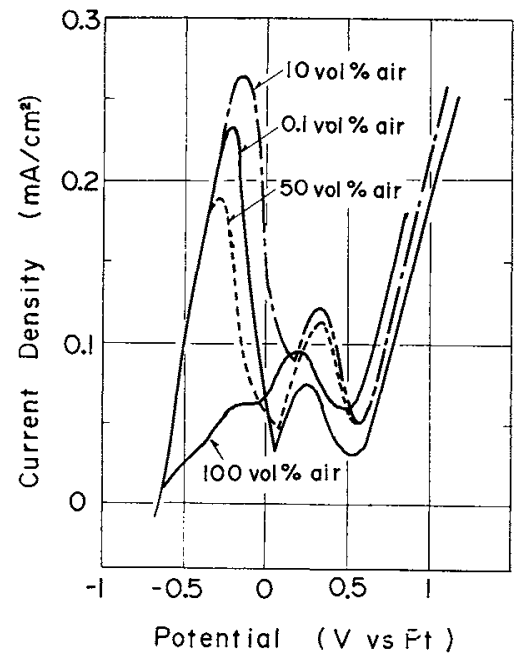

Fig.1 Effect of air on the anodic polarization behavior of $\mathrm{HT} 80$ in liquid $\mathrm{NH}_{3}-\mathrm{NH}_{4}$ $\mathrm{CO}_{2} \mathrm{NH}_{2}$ at $30^{\circ} \mathrm{C}$. The air in the test vessel was replaced with $\mathrm{Ar}$ gas before filling it with liquid ammonia. The air percentages were calculated from the mixing gas before filling the vessel with liquid ammonia.

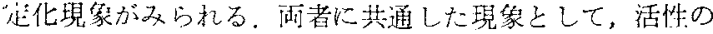
趾が少量の空気混入(10 vol\%)で高くなり，多量の混入て 低くなっている，Fig.2の場合の HT 80 の腐食䢟度は， 空気 0.1 vol $\%$ のとが $0.028 \mathrm{~mm} /$ year, $50 \mathrm{vol} \%$ のを が $0.018 \mathrm{~mm} /$ year, $100 \mathrm{vol} \%$ のさが $0.003 \mathrm{~mm} /$ year

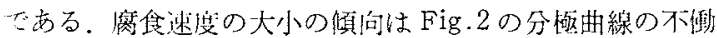
熊化電流傅の大小のそれと一政している。

\section{（2）水分の影響}

$\mathrm{N}_{2}$ ガスで潖控した空気 0.1 vol\% の液体 $\mathrm{NH}_{3}-\mathrm{NH}_{4} \mathrm{CO}_{2}$

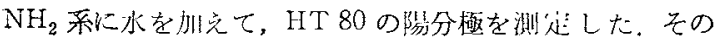

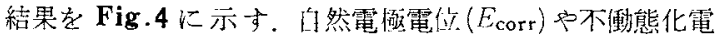

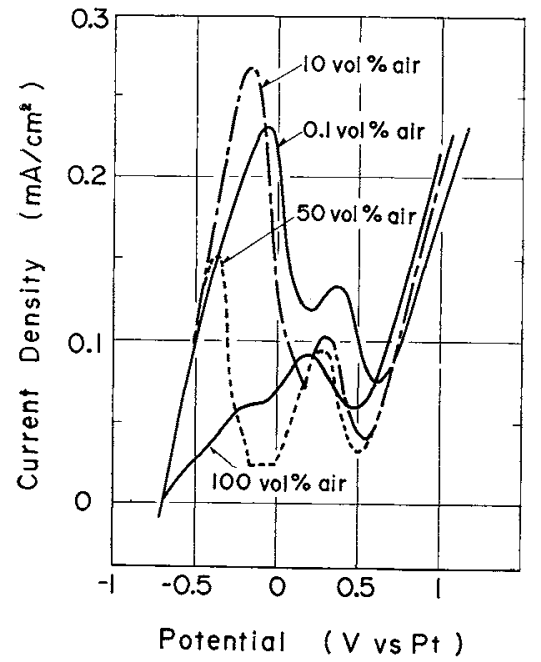

Fig.2 Effect of air on the anodic polarization behavior of $\mathrm{HT} 80$ in liquid $\mathrm{NH}_{3}-\mathrm{NH}_{4} \mathrm{CO}_{2}$ $\mathrm{NH}_{2}$ at $30^{\circ} \mathrm{C}$. The air in the test vessel was replaced with $\mathrm{NH}_{3}$ gas.

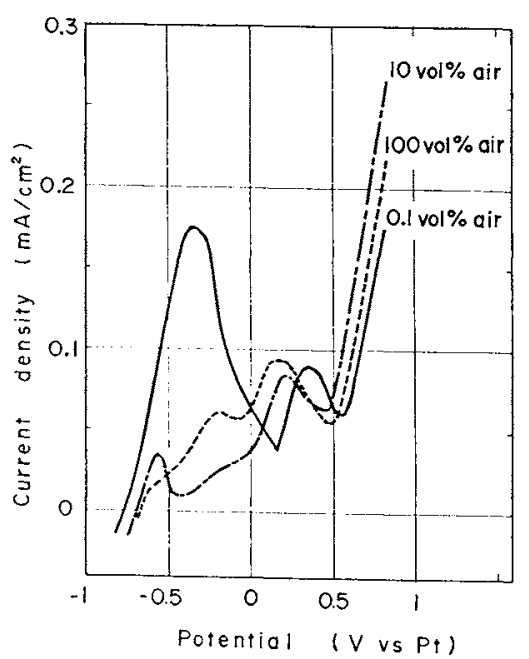

Fig.3 Effect of air on the anodic polarization behavior of $\mathrm{HT}_{4} 80$ in liquid $\mathrm{NH}_{3}-\mathrm{NH}_{4} \mathrm{CO}_{2}$ $\mathrm{NH}_{2}$ at $30^{\circ} \mathrm{C}$. The air in the test vessel was replaced with $N_{2}$ gas ${ }^{(8)}$. 


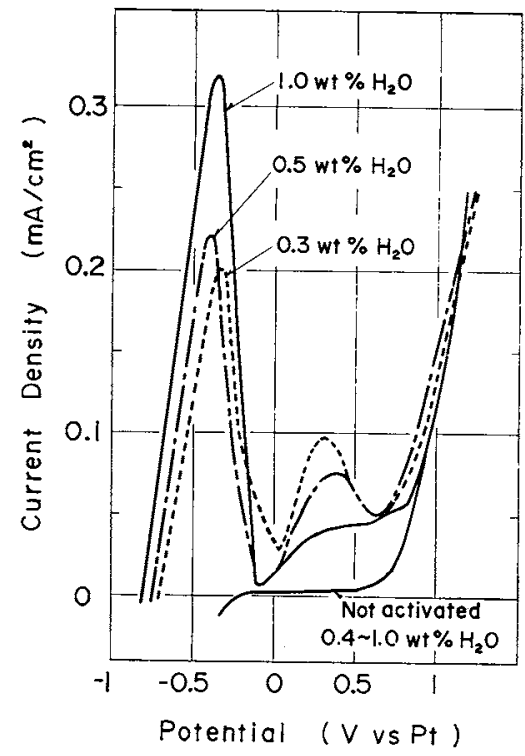

Fig.4 Effect of $\mathrm{H}_{2} \mathrm{O}$ on the anodic polarization behavior of $\mathrm{HT} 80$ in liquid $\mathrm{NH}_{3}-\mathrm{NH}_{4} \mathrm{CO}_{2}$ $\mathrm{NH}_{2}-0.1$ vol\% air at $30^{\circ} \mathrm{C}$. The air in the test vessel was replaced with $\mathrm{N}_{2}$ gas.

位 $\left(E_{P}\right)$ ははとえど变化しないが，水分最の増大とともに不 儌態化電流密度 $\left(I_{C}\right)$ は大きくなり，-0.1〜+0.1 V 付近の 不働態保持電流缺淁 $\left(I_{P}\right)$ は小さくなる傾问を示す。水分を $0.4 \mathrm{wt} \%$ 以上添加与ると, 没せきのままの銅は不動態電位 $\left(E_{\text {corr }}=-0.1 \mathrm{~V}\right)$ を示し，この状態から陽分極すると安这

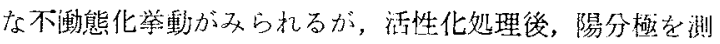

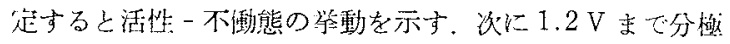

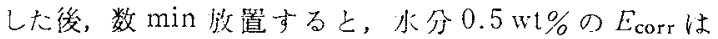
-0.7 V を示方か，水分 $1.0 w t \% の E_{\text {corr }}$ は $-0.1 \mathrm{~V}$ と不 働態電位を示した。

$\mathrm{N}_{2}$ ガスにかえて $\mathrm{NH}_{3}$ ダスで置撸した同一系(空气 0.1 vol $\%$, 液体 $\left.\mathrm{NH}_{3}-\mathrm{NH}_{4} \mathrm{CO}_{2} \mathrm{NH}_{2}-\mathrm{H}_{2} \mathrm{O}\right)$ で水分量を変壳て, HT 80 の陽分極を澌全した。その䋐琹をFig.5に示す。 水分の壇大に伴い片は大きくなり，IPは小さくなること は $\mathrm{N}_{2}$ 置撸の系同しであるが，水を $1.0 \mathrm{wt} \%$ 添加して も，没せきのままで不㗢態化現象を示さない点と，IPが やや大きい圤が $\mathrm{N}_{2}$ 置撸の系と買なっている，また雨者に 共通した現像として，水分を1.0wt\%深加した場合， $0.4 \mathrm{~V}$ 付近にみられる2次活性の山が低くなっていること がかかる。 一j，分桠後の HT 80 電極の表面には，水分 が多い、汪ど青照い皮膜がより厚く付着し，Fig.4で活性状

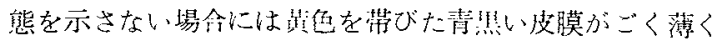
付篔していた。

\section{（3）水分を $0.5 \mathrm{wt} \%$ 添加した場合の空気の影響}

液体 $\mathrm{NH}_{3}-\mathrm{NH}_{4} \mathrm{CO}_{2} \mathrm{NH}_{2}$ 系に水索 $0.5 \mathrm{wt} \%$ 添加儿，空 攴の混入量を变云て，HT80の隄分極を测定した。その

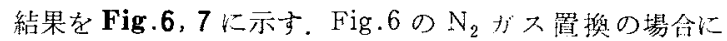

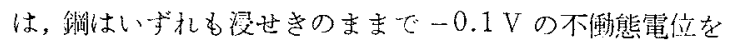

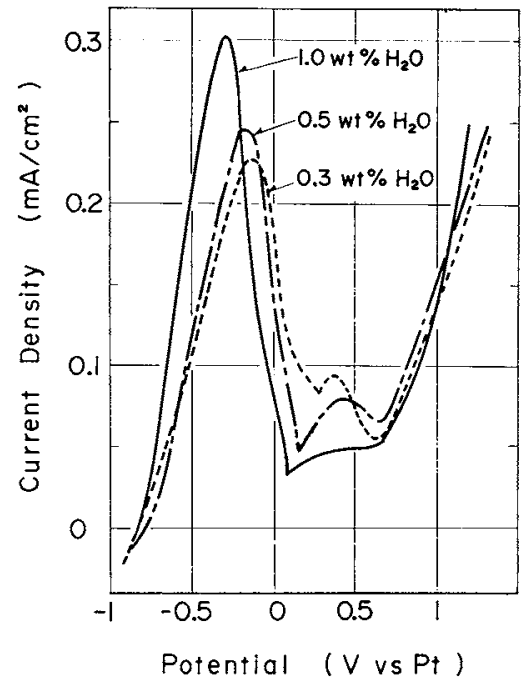

Fig. 5 Effect of $\mathrm{H}_{2} \mathrm{O}$ on the anodic polarization behavior of IIT 80 in liquid $\mathrm{NH}_{3}-\mathrm{NH}_{4} \mathrm{CO}_{2}$ $\mathrm{NH}_{2}-0.1$ vol\% air at $30^{\circ} \mathrm{C}$. The air in the test vessel was replaced with $\mathrm{NH}_{3}$ gas.

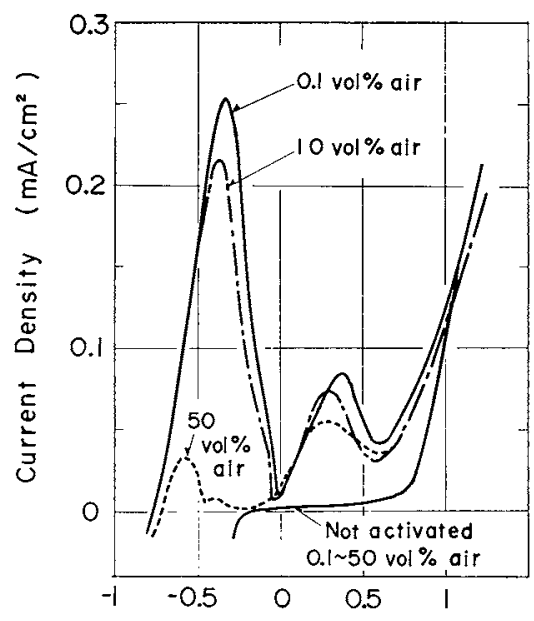

Potential ( $V$ vs Pt)

Fig.6 Effect of air on the anodic polarization behavior of IT 80 in liquid $\mathrm{NH}_{3}-\mathrm{NH}_{4} \mathrm{CO}_{2}$ $\mathrm{NH}_{2}-0.5 \mathrm{wt} \% \mathrm{H}_{2} \mathrm{O}$ at $30^{\circ} \mathrm{C}$. The air in the test vessel was replaced with $\mathrm{N}_{2}$ gas.

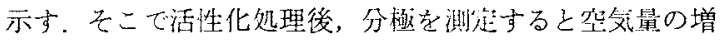
大とともに 1 次活性および 2 次活性の临が低くなり，ピー クを示す電位はそれぞ机繁側に移行する.Fig.7の $\mathrm{NH}_{3}$

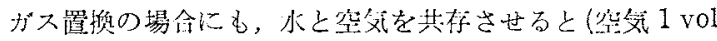
$\%$ 以上，没せきのままで不㗢態電位を示し，活性化処理

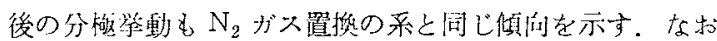

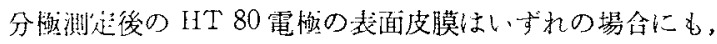

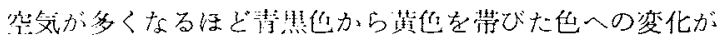
より渚しい。

（4）水分を添加した場合の温度の影粫

$\mathrm{N}_{2}$-固据 L大空父 0.1 rol\% - 液体 $\mathrm{NH}_{3}-\mathrm{NH}_{4} \mathrm{CO}_{2} \mathrm{NH}_{2}-$ 


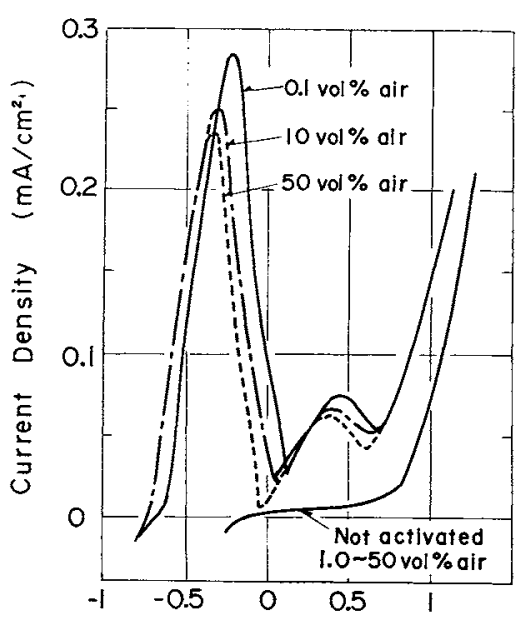

Potential ( $V$ vs $P \dagger$ )

Fig.7 Effect of air on the anodic polarization behavior of $\mathrm{HT} 80$ in liquid $\mathrm{NH}_{3}-\mathrm{NH}_{4} \mathrm{CO}_{2}$ $\mathrm{NH}_{2}-0.5 \mathrm{wt} \% \mathrm{H}_{2} \mathrm{O}$ at $30^{\circ} \mathrm{C}$. The air in the test vessel was replaced with $\mathrm{NH}_{3}$ gas.

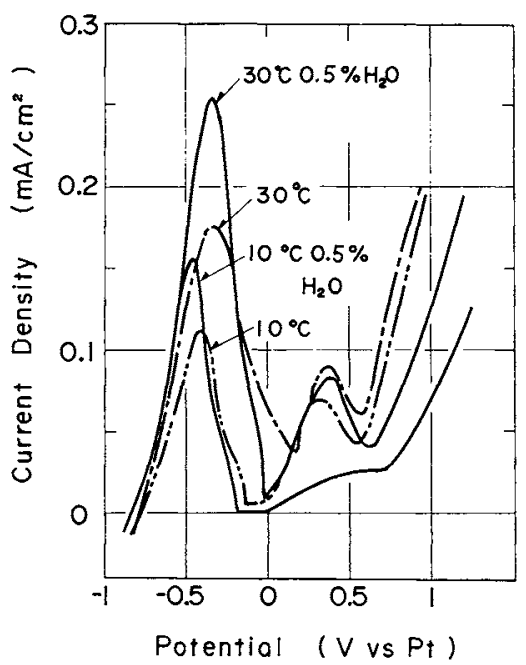

Fig. 8 Effects of $\mathrm{H}_{2} \mathrm{O}$ and temperature on anodic polarization behavior of HT 80 in liquid $\mathrm{NH}_{3}-\mathrm{NH}_{4} \mathrm{CO}_{2} \mathrm{NH}_{2}-0.1$ vol\% air. The air in the test vessel was replaced with $\mathrm{N}_{2}$ gas.

0.5 wt \% $\mathrm{H}_{2} \mathrm{O}$ 系で, $\mathrm{HT} 80$ の陽分㰒を $30^{\circ} \mathrm{C}$ と $10^{\circ} \mathrm{C}$ で澌 造した。その結果をFig.8に水起添加しない場合と刘比 して示す，活性の山は水の添加で高くなるが，渑度の低下 により低くなる。なた不動態領域は温度低下により安起と なり，水を添加するとさらに安定化し，明らかに相乗的効 果が歹らる。ま 2 次活性の山は $10^{\circ} \mathrm{C}, 0.5 \mathrm{wt} \% \mathrm{H}_{2} \mathrm{O}$ の深加のとき, $30^{\circ} \mathrm{C}, 1.0 \mathrm{wt} \% \mathrm{H}_{2} \mathrm{O}$ の添川(Fig.4) と同様 に消失してくる.

\section{2. 自然電栖電位}

水分と空気を同時に添加した液体 $\mathrm{NH}_{3}-\mathrm{NH}_{4} \mathrm{CO}_{2} \mathrm{NH}_{2}$ 系 $\left(30^{\circ} \mathrm{C}\right)$ で，HT 80 は浸せきの劣の状態で不㗢態電位を
示した (Fig.4，6)。この不働態電位領域を空気と水分の関 係でまとめると Fig.9，10のようになる。いずれる $30^{\circ} \mathrm{C}$ に澾 Lて $10 \mathrm{~min}$ 経過後の自然電極電位が，Fig.4，6 力5 $-0.07 \sim-0.19 \mathrm{~V}$ (vs Pt)のときを不働態, $-0.65 \sim-0.75$ V(vsPt)のときを活性と判公した。Fig.9，100， $\mathrm{N}_{2}$ も しくは $\mathrm{NH}_{3}$ ガス置换のいずれの系も，水分 $0.3 \mathrm{wt} \%$ 添加 までは類似した㖽句を示している。さらに水分を $0.4 \mathrm{wt} \%$ 以上添加すると，不働態を示す心必要な空気量は， $\mathrm{N}_{2}$ ガ

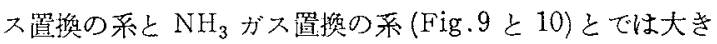
く異なる、しかし，いずれの場合にも，水分を多く(1.0 wt\%)添加しても，少量の空瓶がなければ不働態を示さな i.

$\mathrm{N}_{2}$ ガスで琶換した空父 0.1 vol\% の液体 $\mathrm{NH}_{3}-\mathrm{NH}_{4} \mathrm{CO}_{2}$ $\mathrm{NH}_{2}-0.5 \mathrm{wt} \% \mathrm{H}_{2} \mathrm{O}$ 系に扣ける $\mathrm{HT} 80$ の自然電極電位の 経䏶変化と，腐食速度をFig.11飞示す。浸せきのますで 不働態電位を示したものは $150 \mathrm{hr}$ 後でも不㗢態電位を保

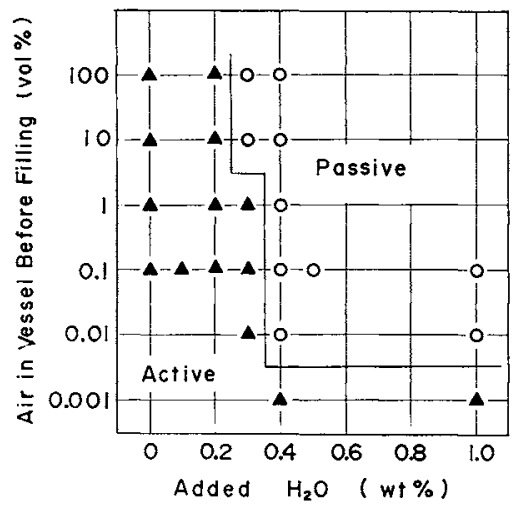

Fig. 9 Active and passive regions for $\mathrm{HT} 80$ as dipped in liquid $\mathrm{NH}_{3}-\mathrm{NH}_{4} \mathrm{CO}_{2} \mathrm{NH}_{2}-\mathrm{H}_{2} \mathrm{O}$-air at $30^{\circ} \mathrm{C}$. The air in the test vessel was replaced with $\mathrm{N}_{2}$ gas, and the air percentage was calculated from the mixing gas before filling the vessel with liquid ammonia.

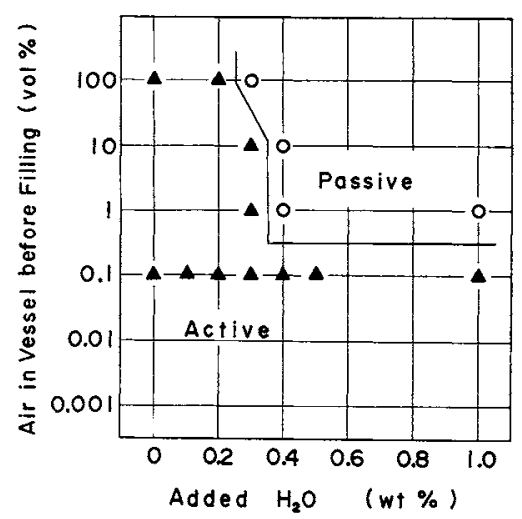

Fig.10 Active and passive regions for $\mathrm{HT} 80$ as dipped in liquid $\mathrm{NH}_{3}-\mathrm{NH}_{4} \mathrm{CO}_{2} \mathrm{NH}_{2}-\mathrm{H}_{2} \mathrm{O}$-air at $30^{\circ} \mathrm{C}$. The air in the test vessel was replaced with $\mathrm{NH}_{3}$ gas. 


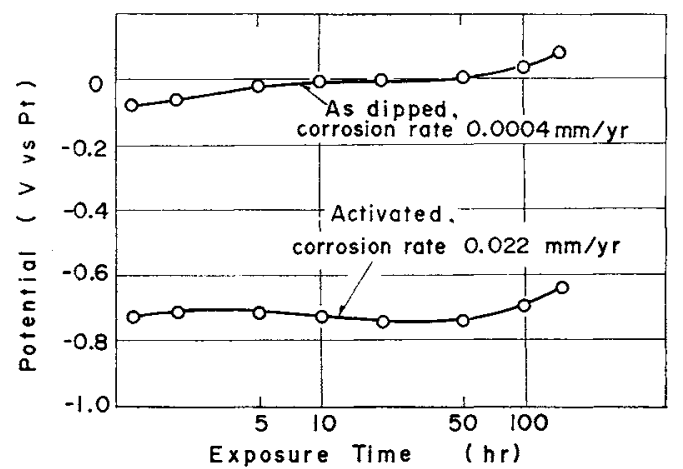

Fig.11 Potential-time curves of $\mathrm{HT} 80$ in liquid $\mathrm{NH}_{3}-\mathrm{NH}_{4} \mathrm{CO}_{2} \mathrm{NH}_{2}-0.5$ wt $\% \mathrm{H}_{2} \mathrm{O}-0.1$ vol $\%$ air at $30^{\circ} \mathrm{C}$. The air in the test vessel was replaced with $\mathrm{N}_{2}$ gas.

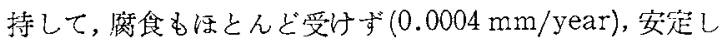
た状態を示している。一方活性化したものは依然として活 性のまを，軽度の腐食を受けている(0.022 mm/year).

したがって腐食速度からみても，この系にお沙鋼の表面 皮膜の安定・不安定加，水分々空気の混入量によって㶧ま るよらに思われる。

\section{3. 応力度食割れ試験}

陽分極峴線が高い活性の山と不安定不働態を示す条件 下，すなわら系内の空気を除去するために， $\mathrm{N}_{2}$, Ar \&乙

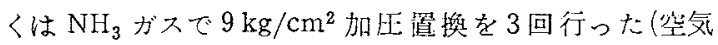
$0.1 \mathrm{vol} \%$ ) 液体 $\mathrm{NH}_{3}-\mathrm{NH}_{4} \mathrm{CO}_{2} \mathrm{NH}_{2}$ 系で，㐫力腐静割れ試 験を行った(21 day) 結果,いずれの試験片る同程度の割れ を発生した。

系内の空気を $\mathrm{N}_{2}$ ガスもしくは $\mathrm{NH}_{3}$ ガスで埴撸した液 体 $\mathrm{NH}_{3}-\mathrm{NH}_{4} \mathrm{CO}_{2} \mathrm{NH}_{2}$ 系の空気量と承分量を変えて, $\mathrm{HT}$ 80 鎆の応力應食割れ試験を行った。 その絬果を Fig.12 $\left(\mathrm{N}_{2}\right.$ 置撸 $), 13\left(\mathrm{NH}_{3}\right.$ 置掺)に示す。水を添加しない場合は,

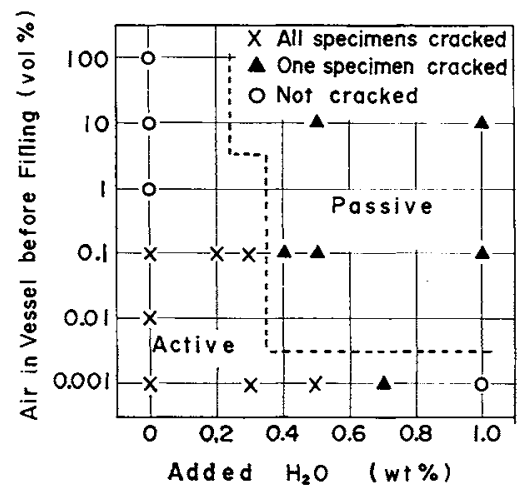

Fig.12 Effects of $\mathrm{H}_{2} \mathrm{O}$ and air on SCC of $\mathrm{HT}$ 80 in liquid $\mathrm{NH}_{3}-\mathrm{NH}_{4} \mathrm{CO}_{2} \mathrm{NH}_{2}$ at $30^{\circ} \mathrm{C}$. The air in the test vessel was replaced with $\mathrm{N}_{2}$ gas, and the air percentage was calculated from the mixing gas before filling the vessel with liquid ammonia. Two specimens were tested for 21 days in each condition.

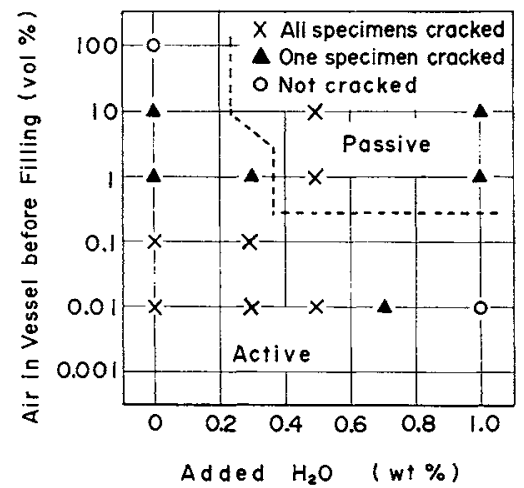

Fig. 13 Effects of $\mathrm{H}_{2} \mathrm{O}$ and air on SCC of $\mathrm{HT} 80$ in liquid $\mathrm{NH}_{3}-\mathrm{NH}_{4} \mathrm{CO}_{2} \mathrm{NH}_{2}$ at $30^{\circ} \mathrm{C}$. The air in the test vessel was replaced with $\mathrm{NH}_{3}$ gas, and other conditions are the same as in Fig.11.

両者と空気が一定量以下の場合には，SCCを発生する。 一方水を添加した場合にも，両者は比較的よく似た傾向を 示している。すなわち，Fig.9，10で活性状態を示す領域 ては，空気と水分が少ないはどSCCを発生しやすく，こ の活性領域で水を $1.0 \mathrm{wt} \%$ 添加すると SCCを発生しなく なる。一方不動態領域では，SCCを発生したり，しなかっ たり，ばらつきがみられ，水を1.0 wt\%添加して子 SCC を発生する場合がある、試験片の䒾面は，活性領域の場合 にはいずれる㝘黑い皮膜で覆われているが，不働態領域の 場合には皮膜の生成が㴓められなかった。

\section{IV. 考察}

$\mathrm{NH}_{4} \mathrm{CO}_{2} \mathrm{NH}_{2}$ 飽和の液体 $\mathrm{NH}_{3}$ 打で, HT 80 の陽分極举: 動は空気恰去に用いた不活性がスの種類, 残存空気量や水 の添加最などによって変化する。したがってHT 80 の SCC 挙動も，混入空気量や承分量によって異なる。前 報 ${ }^{(8)(9)}$ で SCC 惕分極明線の活性の山が高く，不安定な 不働態域を示して，自然腐食電位がこの不安定不働態琙に 保持される場合に発生しやすいことを述べた。この仮距の もとに，各条件下でのSCCの举動を陽分極の挙動と関連 ふけて考察したい。

\section{1. 空気の作用}

液体 $\mathrm{NH}_{3}-\mathrm{NH}_{4} \mathrm{CO}_{2} \mathrm{NH}_{2}$ 采に空気を混入すると，不㗢態

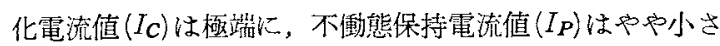
くなり(Fig.1，2)，これらの電流值が小さい場合には SCC が抑制されて(Fig.12，13 の水添加なし)，陽分極の挙動と SCC の間に相関がみられる。しかし空穸除去に用いた $\mathrm{N}_{2}$ ガスと $\mathrm{NH}_{3}$ ガスの間には， SCCを発生し始める限界空気 最に差がみられるとともに，同一空気濃度の下で陽分極期

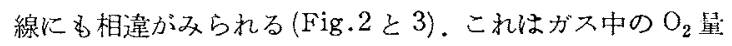
の差や韭状の違い以よる置換時の残存空気量の相違などが 考えられるが， $\mathrm{N}_{2}$ は99.999\%以上のガスを使っているこ と，特よび同一操作で置換を行っているにるかかわらず， 


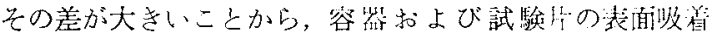
$\mathrm{O}_{2}$ に対寸るそれらがスの影響の差などが考䒚られる。

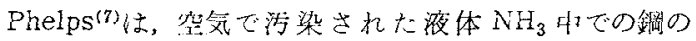
$\mathrm{SCC}$ は $\mathrm{N}_{2}$ 単独では発生しないが， $\mathrm{O}_{2}$ と $\mathrm{N}_{2}$ の共存下で発

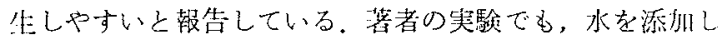

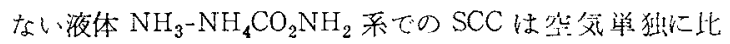
ベて空気と $\mathrm{N}_{2}$ の共存下で発生しや子小しかしこの系で $\mathrm{N}_{2}$ 単独の下です SCC を発生する。このPhelpsとの結染

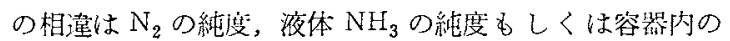
空気除去力法の差など术るのと考兄られる。

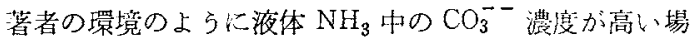
合には， $\mathrm{Ar}, \mathrm{N}_{2}, \mathrm{NH}_{3}$ のいずれのがスで空気を除去して も，SCCを発生する事実から，網のSCC は空気混入量吕 多小場合に抑制され，徽量の場合に加速されるものと考え られる。したがってこの系での霍のSCC は共存する不活 性ガスの種類にはほとんど関係なく，淈入している空気中 の $\mathrm{O}_{2}$ :大きく作用されるものと推察される。液体 $\mathrm{NH}_{3}$ の

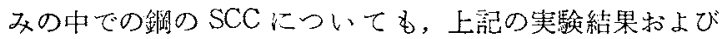
Phelps $の \mathrm{~N}_{2}$ と $\mathrm{O}_{2}$ の共存下で発生しやすいことを考虑す れば，不活性が大むしくは $\mathrm{NH}_{3}$ ガスと $\mathrm{O}_{2}$ の共存下で発 生しやすいるのと予想される。

\section{2. 水分の作用}

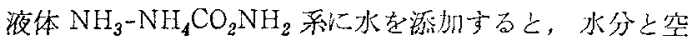
気量との関係で，浸せきのままで，活性と不動態の擷域に わかれる(Fig.9，10)。不㗢態颃域においては， $\mathrm{N}_{2}$ ガスよ りも $\mathrm{NH}_{3}$ ガス置換の方が SCCを発生しやすい傾向にある (Fig.12,13). 活性化後測定した陽分極曲線を比較すると， Fig. 4 の $\mathrm{N}_{2}$ ガス置換 $(0.1 \mathrm{vol} \%$ 空気で，0.5と $1.0 \mathrm{wt} \%$ $\left.\mathrm{H}_{2} \mathrm{O}\right)$ の場合には不動態保持電流值が $0.005 \mathrm{~mA} / \mathrm{cm}^{2}$ で市 るの亿対して, Fig.7 の $\mathrm{NH}_{3}$ ガ大置换 (10 vol\% 空氛で, $\left.0.5 \mathrm{wt} \% \mathrm{H}_{2} \mathrm{O}\right)$ の場合には $0.024 \mathrm{~mA} / \mathrm{cm}^{2}$, 後者が大き

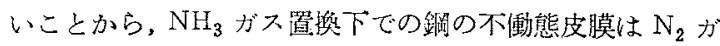
又置換下でのそれに比べて不安芸と推起される。したがっ て漫せき初期に不働態皮膜の一部が破榬された場合，その

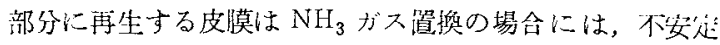
なためSCC 笔生しやすい子のと考方占れる。この皮膜

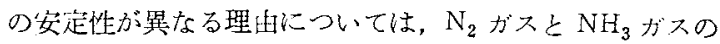
性状の差によるるのと考䒚られるが新細は不䏛である。

いずれのガス置換の場合む，水 $1.0 \mathrm{wt} \%$ の添加で，垽 氛が少ない場合，すなわち自然浸せき状態で活性を示す場 合にはSCC 発生しない，Fig.4，5て，水添加によって 不㗢態化電流值 $\left(I_{\boldsymbol{C}}\right)$ が大きく, 不㗢態保持電流值 $\left(I_{P}\right)$ が小 さくなること，おょびFig.6，7で，空気の減少りよって IC とIPが大きくなることなどか，水分が多くて空気が 少ない場合には，ICが㥛端に大きく，IPは中程度と推定 される。したがってこの昜合は $I_{C} か ゙$ 極端に大きいため， 試験片は活性電位を維持し，全面腐食が優先して，SCCを 発生しなくなったのではないかと推察される。
液体 $\mathrm{NH}_{3}-\mathrm{NH}_{4} \mathrm{CO}_{2} \mathrm{NH}_{2}-0.5$ wt \% $\mathrm{H}_{2} \mathrm{O}$ 系に空父湿入 した条件下で，自然漫せき状態の鋼は不働態電位を示す が，活性化処理によって活性電位を保持する(Fig.11)。 。 た活性化後 $1.0 \mathrm{~V}$ 陽分極後放置すると活性電位に厚 る、したがって没せき状態の不慟態は液中に存在する $\mathrm{O}_{2}$ と $\mathrm{H}_{2} \mathrm{O}$ に関係する腐食反応によるものではなく，銓表面 の初期皮膜もしくは吸算 $\mathrm{O}_{2}$ を介して $\mathrm{H}_{2} \mathrm{O}$ または $\mathrm{OH}^{-} か ゙$ $\mathrm{CO}_{3}^{--}$汇先立って吸祽して，不働態と同じ挙動を示してい るのではないかと考えられる。一方活性化逃理によって銅

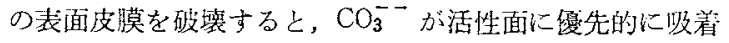
して活性を維掓しているのではないかと考えられる。

水添加に占石不動態化現象は，液体 $\mathrm{NH}_{3}-0.01 \mathrm{wt} \% \mathrm{NH}_{4}$ Cl-0.5 wt \% $\mathrm{H}_{2} \mathrm{O}$ 系でも同じように確㤠された。したがっ

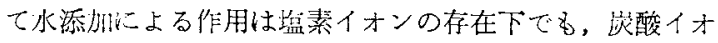
ンの存在下と同じょらな挙動を示すものと予想される。

\section{3. 水添加による液体アンモニアタンクの割れ防止}

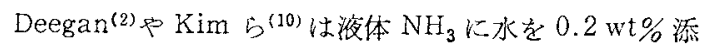

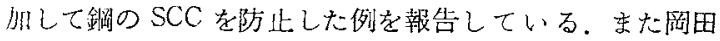
$b^{(3)}$ も液体 $\mathrm{NH}_{3}-\mathrm{CO}_{2}$ 系の電解法による促進試験で， $\mathrm{SCC}$ 防止北必要な水分量は $0.2 \sim 0.5 \mathrm{wt} \%$ で，高強度材任ど多 くの水分を必要とすることを㲔告している，著者の液体 $\mathrm{NH}_{3}-\mathrm{NH}_{4} \mathrm{CO}_{2} \mathrm{NH}_{2}$ 系ては水分 $0.4 \mathrm{wt} \%$ 以上て $\mathrm{SCC}$ の抑 制傾向が想められたが，十分な防边效果は空気の少ない場 合で，水分 $1.0 \mathrm{wt} \%$ のとき初めて確沙できた(Fig.12，

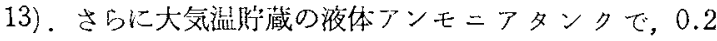
wt\%の水添川による陚駼を行ったが，割れ防此效果が文 ら机なかったこと(Photo.1)などから，条件によっては， 水の添少は SCCの抑制抾として十分なるのとは考えら れない。これは銅の表愐を局部的に侵す $\mathrm{CO}_{3}^{-}$や $\mathrm{Cl}^{-}$の 量，表湎皮膜を安定化させる $\mathrm{O}_{2}$ や水分の量，および使用 温流などの他に，材料側の特珄も関係しているためと考员 られる.

市即の液体 $\mathrm{NH}_{3}$ 中で，鋼は浸せきのま李の状態で不働

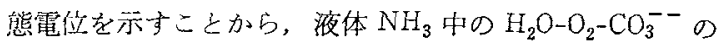
比率によって，活性と不働態の領域に分けられるものと予 想される。すなわり不動態域での $\mathrm{O}_{2}$ と $\mathrm{H}_{2} \mathrm{O}$ の同非添背は 表面皮膜を安运化させるが，活性域での少量の $\mathrm{O}_{2}$ や $\mathrm{H}_{2} \mathrm{O}$ の㳢加は表面皮膜を岀起化させるまでに至らず，SCC の防 北效果が双られない場合も予悡される。Deegan $5^{(2)}$ が用 いたSCC の環境は2 倍の空気量で污染した液体 $\mathrm{NH}_{3}$ であ るため，多くの $\mathrm{O}_{2}$ を溶解しており，液体 $\mathrm{NH}_{3}$ 中の $\mathrm{O}_{2}$ は 実测で数 ppm あり，200 の飽和量は $100 \mathrm{ppm}$ 前媵で， その差は大きい. Deegan らはこの恐気で污染した液体 $\mathrm{NH}_{3}$ 中で，承分 $0.08 \mathrm{wt} \%$ から腐伎割れの㧕制效果が現か れると報じていることから，水添加によるSCC の防止に は液体 $\mathrm{NH}_{3}$ 中の $\mathrm{O}_{2}$ が大さく関当している。のと推察さ れる。以上のことょり，液体アンモニアタンクのSCCを 水添加によって防止するには，液体 $\mathrm{NH}_{3}$ 中の水分の他に $\mathrm{O}_{2}$ 濃度や温度を規制すべきるのと推察される。 


\section{V. 結 言}

腐食割孔促谯噮境下（洨体 $\mathrm{NH}_{3}$-館和 $\mathrm{NH}_{4} \mathrm{CO}_{2} \mathrm{NH}_{2}, 30$

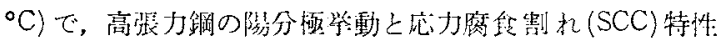

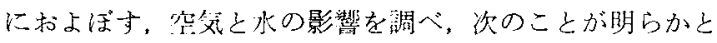
なった。

（1）水を添加しない系では，空気除去を $\mathrm{N}_{2}, \mathrm{Ar}$ もしく は $\mathrm{NH}_{3}$ ガスで行った場合，间一空気濃度の下です，陽分

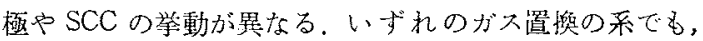
鋼はSCC を発生するが，空気の鼠入に上って，活性の山 は低くなり，不動態は安定化されて SCC と歷食が抑制さ れる。

（2）水と空父を添加した系では，陽分極曲線の活性の山 は水の添加量とともに高くなり，空気量の增加および温度 の低下ととるに低くなる。一方不慟態保持電流值は空受や 水の添加量の堌大抢よび温度の低下ととるに隇少する。

(3) 水 $0.3 \mathrm{wt} \%$ 以上添加の系で，浸せきしたままの鋼 は，空気が多い場合には不動䔮電位を示して腐食され難く なるが，空気が少ない場合には活性電位を示して㦄传され やすい.

（4）水を添加した(最高 $1.0 \mathrm{wt} \%$ )系で，浸せき状態で 活性電位を示す場合の試験扸は，水 $1.0 \mathrm{wt} \%$ の添加で SCC を発生しないが，水分や空気量が少ないはどSCCを 発生しやすくなる。一万不㗢態電位を示す場合にはSCC の結果がばらつく。
(5) 液体 $\mathrm{NH}_{3}$ タンクの SCC を水被にて防止するに は, 液中の $\mathrm{CO}_{3}^{--}, \mathrm{O}_{2}$ の量占上び舀度によって, その必要 限界量が大きく変化する。のと予想さ机る。したがって水 の㕛一律に0.2 wt\%以上と限公するのは閏題である。

終りに，本砸究を行らにあたり有益な助言をいたたいた

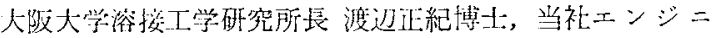

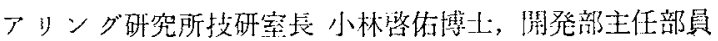

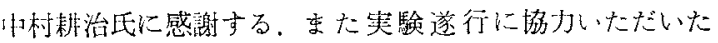
山湖五雄氏に感謝の意を表したい。

\section{文献}

(1) A.W.Loginow and E.1I.Phelps: Corrosion, 18 (1962), $299 \mathrm{t}$.

(2) D.C.Deegan and B.E. Wilde : Corrosion, 29 (1973), 310.

（3）阔田秀贸, 内滕浩光, 堀田 涉: 日本鉄鋼協会第 86 回講演要旨集，(1973)，317.

(4) F.J.Radd and D.H.Oertle : NACE Anual Conference, 1917, March.

（5）今川博之：第20回腐食防食詂論会講演要旨集, (1973), 309.

(6) J.Hutchings, G. Sanderson and D.G.S.Davies: Ammonia Plant Safety Related Facilities, 14 (1972), 102.

(7) E.H.Phelps : Ammonia Plant Safety Related Facilities, 16(1974), 32 .

(8) 今师博之：金属学会誌，40(1976)，1256.

(9) 今川搏之：金属学会誌，41(1977)，211.

(10) C.D.Kim, B.E.Wilde and E.H.Phelps : Corrosion, 31(1975), 255.

\title{
イオン窒化処理した鋼のころがり摩耗特性*
}

\author{
垫野 兵衛** 岡本康 治** \\ 忪田昭 三** 喜 多清**
}

Hyoe Ono, Koji Okamoto, Shozo Matsuda and Kiyoshi Kita : Rolling Wear Properties of Ion Nitrided Steels. Wear properties of ion nitrided low alloyed steels (SCM 3 and SACM 1) and a mild steel (S15C) were studied in comparison with the cases of conventional gas nitriding and tufftriding processes.

Rolling wear tests were done under dry and wet conditions with $9 \%$ slip ratio, using a Nishihara type rolling wear testing machine. The contact stresses were 60 or $50 \mathrm{~kg} / \mathrm{mm}^{2}$.

The results obtained were as follows.

(1) In the case of low alloyed steels, the difference in wear properties tested under dry condition was hardly recognized.

(2) Under wet condition, the ion nitriding was superior in both initial wear loss and wear ratio to the other processes.

(3) As for the ion nitriding, there was little difference in wear properties with regard to the nitriding conditions.

(4) The wear properties with nitriding condition were considered to be caused by the 